\title{
Gambaran kadar ureum pada pasien penyakit ginjal kronik stadium 5 non dialisis
}

\author{
${ }^{1}$ Irendem K. A. Loho \\ ${ }^{2}$ Glady I. Rambert \\ ${ }^{2}$ Mayer F. Wowor
}

\author{
${ }^{1}$ Kandidat Skripsi Fakultas Kedokteran Universitas Sam Ratulangi Manado \\ ${ }^{2}$ Bagian Patologi Klinik Fakultas Kedokteran Universitas Sam Ratulangi Manado \\ Email: irendemk.aloho_12263@hotmail.com
}

\begin{abstract}
Chronic kidney disease (CKD) is a pathophysiological process with diverse etiology, resulting in a progressive decreased in renal function, and generally ends up with kidney failure. In CKD patient, the level of urea increases -uremia- a clinical syndrome that occurs in all organs due to the increased level of urea. During catabolism process, protein is broken down into amino acids and deamination ammonia which is further synthesized to become urea. Increased level of urea depends on the glomerular filtration rate (GFR). Decreased of GFR $(<15 \mathrm{ml} / \mathrm{min})$ can cause renal failure and uremia. This study aimed to determine the levels of urea in patients with stage 5 CKD non-dialysis. This was an observational descriptive study. This study was conducted from December 2015 to January 2016 at two hospitals, Prof. Dr. R. D. Kandou Hospital and Adventist Hospital Manado. Samples were blood samples of all patients suffering from CKD stage 5 non-dyalisis within the specified time. The results of laboratory tests showed that of 35 patients diagnosed with stage 5 CKD non-dialysis all had increased urea levels (100\%). Conclusion: There was an increase in urea level of patients with stage 5 chronic kidney disease non-dialysis either of outpatients or inpatients.
\end{abstract}

Keywords: urea serum, stage 5 non-dialysis chronic kidney disease.

\begin{abstract}
Abstrak: Penyakit ginjal kronik (PGK) merupakan suatu proses patofisiologi dengan etiologi beragam, mengakibatkan penurunan fungsi ginjal yang progresif dan umumnya berakhir dengan gagal ginjal. Umumnya pada PGK terjadi peningkatan kadar ureum dan mengakibatkan terjadinya uremia yaitu suatu sindrom klinik yang terjadi pada semua organ akibat meningkatnya kadar ureum. Dalam proses katabolisme, protein dipecah menjadi asam amino dan deaminasi ammonia yang selanjutnya disintesis menjadi urea. Peningkatan kadar ureum bergantung pada tingkat laju filtrasi glomerulus (LFG). Pada penurunan LFG $(<15 \mathrm{ml} / \mathrm{mnt})$ dapat terjadi gagal ginjal dan uremia. Penelitian ini bertujuan untuk mengetahui gambaran kadar ureum pada pasien penyakit ginjal kronik stadium 5 non-dialisis. Jenis penelitian ini ialah deskriptif observasional. Penelitian dilakukan sejak Desember 2015-Januari 2016 di RSUP Prof. Dr. R. D. Kandou dan RS Advent Teling Manado. Sampel penelitian ialah sampel darah dari semua pasien yang menderita penyakit ginjal kronik stadium 5 nondialisis dalam kurun waktu yang ditentukan. Hasil pemeriksaan laboratorium dari 35 pasien yang terdiagnosis penyakit ginjal kronik stadium 5 non dialisis memperlihatkan peningkatan kadar ureum serum (100\%). Simpulan: Terjadi peningkatan kadar ureum serum pada pasien penyakit ginjal kronik stadium 5 non-dialisis baik yang dirawat jalan maupun dirawat inap.
\end{abstract}

Kata kunci: ureum, penyakit ginjal kronik stadium 5 non dialisis

Ureum merupakan produk akhir dari metabolisme asam amino. Dalam amino dan deaminasi ammonia. Amonia 
dalam proses ini di sintesis menjadi urea. Ureum adalah produk limbah dari pemecahan protein dalam tubuh. Siklus urea (disebut juga siklus ornithine) adalah reaksi pengubahan ammonia $\left(\mathrm{NH}_{3}\right)$ menjadi urea $\left(\mathrm{CO}\left(\mathrm{NH}_{2}\right)_{2}\right){ }^{1}$

Reaksi kimia ini sebagian besar terjadi di hati dan sedikit terjadi di ginjal. Hati menjadi pusat pengubahan ammonia menjadi urea terkait fungsi hati sebagai tempat menetralkan racun. Urea bersifat racun sehingga dapat membahayakan tubuh apabila menumpuk di dalam tubuh. ${ }^{1,2}$ Meningkatnya urea dalam darah dapat menandakan adanya masalah pada ginjal. Peningkatan nitrogen urea darah (BUN) dapat di sebabkan oleh prerenal (dekompensasi jantung, dehidrasi yang berlebihan, peningkatan katabolisme protein dan diet tinggi protein), penyebab renal (glomerulonephritis akut, nefritis kronis, penyakit ginjal polikistik, dan nekrosis tubular ) dan penyebab postrenal (semua jenis obstruksi pada saluran kemih, seperti batu ginjal, kelenjar prostat yang membesar dan tumor)., ${ }^{2,3}$

Peningkatan kadar ureum darah bergantung pada tingkat kerusakan LFG. Pada LFG sebesar 60\%, pasien masih belum merasakan keluhan tapi sudah terjadi peningkatan kada urea dan kreatinin serum. Pada LFG 30\%, mulai terjadi keluhan seperti nokturia, badan lemah, mual, nafsu makan kurang, dan penurunan berat badan. Pada LFG <30\% pasien memperlihatkan gejala dan tanda uremia yang nyata, seperti anemia, peningkatan tekanan darah, mual dan sebagainya, sedangkan pada LFG 15\% akan terjadi gejala dan komplikasi yang lebih serius antara lain dialisis atau transplantasi ginjal. Beberapa komplikasi yang manifestasinya sesuai dengan derajat penurunan fungsi ginjal yang terjadi antara lain pada penurunan LFG sedang (30$59 \mathrm{ml} / \mathrm{mnt}$ ) terjadi hiperfosfatemia, hipokalcemia, anemia, hiperparatiroid, hipertensi dan hiperhomosistinemia, penurunan LFG berat (15-29ml/mnt) terjadi malnutrisi, asidosis metabolic, cenderung hiperkalemia, dan dislipidemia, dan pada penurunan fungsi LFG $(<15 \mathrm{ml} / \mathrm{mnt})$ dapat terjadi gagal ginjal dan uremia. ${ }^{4}$

Uremia adalah suatu sindrom klinik dan laboratorik yang terjadi pada semua organ akibat penurunan fungsi ginjal pada penyakit ginjal, dimana terjadi retensi sisa pembuangan metabolisme protein, yang di tandai oleh homeostasis cairan yang abnormal dan elektrolit dengan kekacauan metabolik dan endokrin. Kadar ureum yang tinggi dan berlangsung kronik merupakan penyebab utama manifestasi dari sindrom uremia, yang di bagi dalam beberapa bentuk yaitu: 1) Pengaturan fungsi regulasi dan eksresi yang buruk, seperti keseimbangan volume cairan dan elektrolit, keseimbangan asam basa, retensi nitrogen dan metabolisem lain, serta gangguan hormonal; dan 2) Abnormalitas sistem tubuh (sistem gastrointenstinal, hematologi, pernafasan, kardiologi, kulit dan neuromuscular). ${ }^{5}$

Penyakit ginjal kronik (PGK) merupakan suatu proses patofisiologi dengan etiologi beragam, mengakibatkan penurunan fungsi ginjal yang progresif dan pada umumnya berakhir dengan gagal ginjal. Kriteria penyakit ginjal kronik yaitu kerusakan ginjal (renal damage) yang terjadi lebih dari 3 bulan, serta adanya tanda kelainan ginjal, termasuk kelainan dalam komposisi darah atau urin, atau kelainan dalam tes pencitraan (imaging tests). Dengan penurunan LFG kurang dari $60 \mathrm{ml} / \mathrm{menit} / 1,73 \mathrm{~m}^{2}$ selama 3 bulan, dengan atau tanpa kerusakan ginjal. ${ }^{4}$ Di Amerika Serikat jumlah pasien penyakit ginjal kronik pada tahun 1991 terdapat 209.000 pasien hingga tahun 2004 terdapat 472.000 orang yang menderita penyakit ginjal kronik. ${ }^{6}$ WHO memperkirakan di Indonesia akan terjadi peningkatan penderita gagal ginjal pada tahun 1995-2025 sebesar 41,4\% dan menurut data dari Persatuan Nefrologi Indonesia (PENEFRI) di perkirakan terdapat 70.000 penderita gagal ginjal di Indonesia, angka ini akan terus meningkat sekitar $10 \%$ setiap tahunnya. ${ }^{7}$ Di Sulawesi utara angka kejadian penyakit ginjal kronik tahun 2013-2014 sebanyak 989 kasus (Dinkes, 2015). ${ }^{8}$ 


\section{METODE PENELITIAN}

Jenis penelitian ini ialah deskriptif observasional. Penelitian dilaksanakan di dua rumah sakit yaitu RSUP. Prof. Dr. R. D. Kandou Manado dan Rumah Sakit Advent Manado selama bulan Desember 2015 sampai Januari 2016. Sampel penelitian ialah sampel darah dari semua pasien penyakit ginjal kronik stadium 5 non dialisis dalam kurun waktu dan sesuai kriteria yang telah ditentukan dengan cara non-probability sampling jenis consecutive sampling.

\section{HASIL PENELITIAN}

Tabel 1. Distribusi pasien penyakit ginjal kronik stadium 5 non dialisis menurut usia

\begin{tabular}{ccc}
\hline $\begin{array}{c}\text { Usia } \\
\text { (tahun) }\end{array}$ & Jumlah & $\%$ \\
\hline $26-35$ & 1 & 2,9 \\
$36-45$ & 2 & 5,7 \\
$46-55$ & 8 & 22,9 \\
$56-65$ & 7 & 20,0 \\
$66-75$ & 13 & 37,1 \\
$>75$ & 4 & 11,4 \\
Jumlah & 35 & 100,0 \\
\hline
\end{tabular}

Tabel 2. Distribusi pasien penyakit ginjal kronik stadium 5 non dialisis menurut jenis kelamin

\begin{tabular}{ccc}
\hline Jenis kelamin & Jumlah & $\%$ \\
\hline Laki-laki & 21 & 60 \\
Perempuan & 14 & 40 \\
Jumlah & 35 & 100 \\
\hline
\end{tabular}

Tabel 3. Distribusi pasien penyakit ginjal kronik stadium 5 non dialisis menurut riwayat penyakit dahulu

\begin{tabular}{ccc}
\hline $\begin{array}{c}\text { Riwayat penyakit } \\
\text { dahulu }\end{array}$ & Jumlah & $\%$ \\
\hline Hipertensi & 29 & 83 \\
Diabetes mellitus & 8 & 23 \\
Asam urat & 15 & 43 \\
\hline
\end{tabular}

Tabel 4. Distribusi pasien penyakit ginjal kronik stadium 5 non dialisis menurut hasil pemeriksaan ureum

\begin{tabular}{cccc}
\hline $\begin{array}{c}\text { Jenis } \\
\text { kelamin }\end{array}$ & Jumlah & $\%$ & $\begin{array}{c}\text { Rerata kadar } \\
\text { ureum } \\
(\mathrm{mg} / \mathrm{dL})\end{array}$ \\
\hline Laki-laki & 21 & 60 & 138,45 \\
Perempuan & 14 & 40 & 140,75 \\
\hline
\end{tabular}

Tabel 5. Distribusi hasil pemeriksaan ureum pasien penyakit ginjal kronik satium 5 non dialisis berdasarkan jenis pelayanan medis

\begin{tabular}{cccc}
\hline $\begin{array}{c}\text { Pelayanan } \\
\text { medis }\end{array}$ & Jumlah & $\%$ & $\begin{array}{c}\text { Rerata kadar } \\
\text { ureum } \\
\text { (mg/dL) }\end{array}$ \\
\hline Rawat jalan & 17 & 48,6 & 142,64 \\
Rawat inap & 18 & 51,4 & 136,28 \\
\hline
\end{tabular}

\section{BAHASAN}

Berdasarkan data yang di peroleh pada Tabel 1, terdapat 1 orang (2,9\%) pada kelompok usia 26-35 tahun, 2 orang (5,7\%) pada kelompok usia 36-45 tahun, 8 orang (22,9\%) pada kelompok usia 46-55 tahun, 7 orang $(20,0 \%)$ pada kelompok usia 56-65 tahun, 13 orang pada kelompok usia 66-75 tahun $(37,1 \%)$, dan 4 orang diatas 75 tahun (11,4\%). Berdasarkan pengelompokan ini dapat dilihat bahwa kelompok usia 66-75 tahun terbanyak mengalami penyakit ginjal kronik stadium 5 yang non-dialisis. Hasil penelitian ini agak berbeda dengan penelitian oleh Nur Dinah et al. yang mendapatkan kelompok usia 61-70 tahun sebesar $45 \%$ dari penderita penyakit ginjal kronik stadium 5 yang non-dialisis. ${ }^{9}$ Berbeda dengan data dari United States Renal Data System (USRDS) yang menunjukkan bahwa kelompok umur 45-64 tahun (45\%) merupakan kelompok usia terbanyak yang menderita penyakit ginjal kronik stadium 5 non-dialisis. ${ }^{10}$ Berdasarkan hasil ini, prevalensi penyakit ginjal kronik meningkat pada usia lanjut.

Tabel 2 memperlihatkan bahwa pasien yang terdiagnosis penyakit ginjal kronik stadium 5 non-dialisis, terdapat 21 orang laki-laki (60\%) dan 14 orang perempuan (40\%). Hasil ini sama dengan data United States Renal Data System (USRDS) yang 
menunjukkan bahwa pasien laki-laki (56,8\%) lebih banyak dari perempuan (43,2\%). ${ }^{10}$ Berbeda dengan hasil penelitian Melti et al. ${ }^{8}$ yang menyatakan bahwa perempuan $(70 \%)$ lebih banyak dibanding dengan laki-laki (30\%). Hasil-hasil penelitian yang berbeda menunjukkan bahwa jenis kelamin tidak berpengaruh pada prevalensi penyakit ginjal kronik.

Pada Tabel 3 terlihat pasien yang terdiagnosis penyakit ginjal kronik stadium 5 non-dialisis, terdapat 29 orang dengan riwayat hipertensi, 8 orang dengan riwayat diabetes mellitus, 15 orang dengan riwayat asam urat. Hasil ini mirip dengan penelitian oleh Suryadi et al. bahwa hipertensi (68,9\%) dan diabetes melitus (33,3\%) merupakan faktor risiko terbanyak. Dari pembagian ini dapat dilihat bahwa hipertensi merupakan faktor risiko yang terbanyak pada pasien penyakit ginjal kronik stadium 5 non-dialisis. Pada umumnya gagal ginjal terjadi karena kerusakan progresif akibat tekanan tinggi pada kapiler-kapiler glomerulus, darah akan mengalir ke unit-unit fungsional ginjal, neuron akan terganggu, dan dapat berlanjut menjadi dan kematian. Dengan rusaknya membran glomerulus, protein akan keluar bersamaan dengan urin, sehingga tekanan osmotik koloid plasma berkurang. Hal ini menyebabkan edema yang sering di jumpai pada hipertensi kronik. Ginjal mengendalikan tekanan darah dengan cara: 1) Jika tekanan darah meningkat, ginjal akan menambah pengeluaran garam dan air, yang akan menyebabkan berkurangnya volume darah dan mengembalikan tekanan darah ke normal; 2) Jika tekanan darah menurun, ginjal akan mengurangi pembuangan garam dan air, sehingga volume darah bertambah dan tekanan darah kembali normal; dan 3) ginjal juga bisa meningkatkan tekanan darah dengan menghasilkan enzim yang disebut renin, yang memicu pembentukan hormone angiotensin, yang selanjutnya akan memicu pelepasan hormon aldosteron. $^{11}$

Ginjal merupakan organ penting dalam mengendalikan tekanan darah, oleh karena itu berbagai penyakit dan kelainan pada ginjal bisa menyebabkan teradinya tekanan darah tinggi, jika terjadi penyempitan arteri yang menuju ke salah satu ginjal, selain itu juga bisa menyebabkan peradangan dan cedera pada satu atau kedua ginjal, selain itu juga bisa menyebabkan naiknya tekanan darah. $^{12}$

Peningkatan tekanan darah hingga melebihi ambang batas normal (hipertensi) dapat menyebabkan gangguan fungsi ginjal dan munculnya penyakit ginjal. Hipertensi dapat menyebakan pembuluh darah pada ginjal mengerut sehingga aliran zat-zat makanan menuju ginjal teganggu dan mengakibatkan kerusakan sel-sel ginjal. Jika hal ini terjadi secara terus-menerus maka sel-sel ginjal tidak akan berfungsi lagi. ${ }^{12}$

Pada Tabel 4, dapat dilihat dari 35 pasien yang terdiagnosis penyakit ginjal kronik stadium 5 non-dialisis seluruhnya (100\%) mengalami peningkatan kadar ureum dengan rerata kadar ureum pada laki-laki sebesar $138,45 \mathrm{mg} / \mathrm{dL}$ dan perempuan sebesar 140,75mg/dL. Dari hasil tersebut dapat dilihat bahwa perempuan memiliki kadar ureum yang lebih tinggi daripada laki-laki. Peningkatan kadar ureum pada 35 pasien penyakit ginjal kronik stadium 5 non-dialisis menunjukkan bahwa meningkatnya ureum dalam darah dapat menjadi sebuah tanda kerusakan ginjal.

Peningkatan kadar ureum darah bergantung pada penurunan fungsi filtrasi glomerulus. Penurunan fungsi ginjal 15\% $(<15 \mathrm{ml} / \mathrm{mnt})$ mengindikasikan adanya gagal ginjal dan uremia. Fungsi ginjal antara lain mengatur keseimbangan asam basa, hormonal/eritropoetin dan ekskresi sampah sisa metabolisme seperti ureum. ${ }^{5}$ Bila ureum tidak di keluarkan dalam tubuh dapat terjadi sindrom uremia. Sindrom uremia ini terutama terjadi pada penderita penyakit ginjal yang kronis dan akan memberikan manifestasi pada bagian anggota tubuh yang lain seperti gastrointenstinal, kulit, hematologi, saraf dan otot, kardiovaskuler, endokrin dan sistem lainnya berupa kerusakan. Oleh 
karena itu peningkatan kadar ureum maupun kreatinin dapat di gunakan sebagai indikator penting untuk mengetahui fungsi ginjal.

Pada Tabel 5, terlihat dari 35 pasien penyakit ginjal kronik stadium 5 nondialisis, terdapat 17 pasien rawat jalan (48,6\%) dan 18 pasien rawat inap (51,4\%) dengan rerata kadar ureum pasien rawat jalan 142,64mg/dL dan rawat inap 136,28mg/dL. Hasil tersebut menunjukkan baik pasien rawat jalan maupun rawat inap mengalami peningkatan kadar ureum, namun rerata kadar ureum pasien rawat jalan sedikit lebih meningkat dibanding rerata kadar ureum pasien rawat inap. Perubahan pada hasil ini bisa dipengaruhi oleh berbagai faktor seperti penggunaan obat-obatan yang dapat meningkatkan atau menurunkan kadar ureum.

Kelemahan penelitian ini ialah tidak dilakukan uji beda kadar ureum antara pasien rawat inap dan rawat jalan karena tidak dilakukannya anamnesis yang komprehensif untuk mencari faktor-faktor yang terkait dengan pasien yang masuk di rawat inap seperti adanya intervensi pada pasien sebelum pengambilan sampel darah antara lain obat-obatan dan makanan yang dikonsumsi oleh pasien; dan juga penyakit yang mendasari pasien PGK stadium 5 non-dialisis yang masuk di RSUP Prof. Dr. R.D Kandou Manado dan RS Advent Teling.

\section{SIMPULAN}

Berdasarkan hasil penelitian ini maka dapat disimpulkan bahwa pada penyakit ginjal kronik stadium 5 non-dialisis terjadi peningkatan kadar ureum serum. Kadar ureum serum pasien yang dirawat jalan $(142,64 \mathrm{mg} / \mathrm{dL})$ lebih tinggi daripada pasien yang dirawat inap $(136,28 \mathrm{mg} / \mathrm{dL})$. Peningkatan ureum terbanyak terjadi pada usia 66-75 tahun dan lebih banyak pada laki-laki dibandingkan perempuan.

\section{DAFTAR PUSTAKA}

1. Weiner D, Mitch WE, Sands JM. Urea and ammonia metabolism and the control of renal nitrogen excretion. Clin J Am
Soc Nephrol. 2015;10:1444-1458. doi: 10.2215/CJN.10311013.

2. Kamal A. Estimation of blood urea (BUN) and serum creatinin level in patients of renal disorder. Ind J Fund Appl Life Sci. 2014;4(4):199-202.

3. Albright RC. Acute renal failure: a practical update. Mayo Clin Proc. 2001;76:6774.

4. Suwitra K. Penyakit ginjal kronik. In: Sudoyo AW, Setiyohadi B, Alwi I, Simadibrata M, Setiati S, editors. Buku Ajar Ilmu Penyakit Dalam Jilid II (5th ed). Jakarta: Interna Publishing: Pusat Penerbitan Ilmu Penyakit Dalam, 2010; p.1036-38.

5. Wilson LM. Penyakit ginjal kronik stadium akhir: sindrom uremik. In: Pendit BU, Hartanto H, Wulansari P, Mahanani DA, Susi N (editor Bahasa Indonesia). Patofisiologi konsep klinis proses-proses penyakit Vol-2 (6th ed). Jakarta: EGC, 2005; 45.p. 951-62.

6. Patambo KK, Rotty LWA, Palar S. Gambaran status besi pada pasien penyakit ginjal kronik yang menjalani hemodialisis. Jurnal e-Clinic (eCl). 2014;2(2).

7. Melti T, Mongan A, Manopo F. Hubungan antara derajat penyakit ginjal kronik dengan nilai agregasi trombosit. Jurnal e-Biomedik. 2014;2:509.

8. Muchtar NR, Tjitrosantoso H, Bodhi W. Studi penggunaan obat antihipertensi pada pasien gagal ginjal kronik yang menjalani perawatan di RSUP Prof. Dr. R. D. Kandou Manado periode Juli 2013-Juni 2014. Jurnal Ilmu Farmasi. 2015;4(3):22-3.

9. Mamonto ND, Standy S, Heriyannis $H$. Identifikasi bakteri aerob pada urin porsi tengah pasien penyakit ginjal kronik stadium 5. Jurnal e-BM. 2015;3(1):211-15.

10. Nicola LD, Minutolo R, Chiodini P, Borrelli S, Zoccali C, Postorino M, et al. The effect of increasing age on the prognosis of non-dialysis patients with chronic kidney disease receiving stable nephrology care. Kidney Int. 2012;82:482-8. doi: 10.1038/ki.2012.174.

11. Tjekyan RMS. Prevalensi dan factor resiko penyakit ginjal kronik di RSUP Dr. 
Lobo, Rambert, Wowor: Gambaran kadar ureum...

Mohammad Hoesin Palembang tahun 2012. MKS. 2014;4:277-80.

12. Asriani, Bahar B, Kadrianti B. Hubungan hipertensi dengan kejadian gagal ginjal di rumah sakit IBNU Sina Makasar periode Januari 2011Desember 2012. Jurnal Ilmiah Kesehatan Diagnosis. 2014;4(2):163-7. 